\title{
16. Public leadership and the social construction of economic catastrophe
}

\author{
Paul 't Hart and Karen Tindall
}

\section{Meaning-making predicaments}

In a study of Alan Greenspan's rhetorical leadership, Bligh and Hess (2007:98) state:

It is entirely possible that in a post-crisis situation characterised by tremendous uncertainty, no prior cases or precedents to examine, or previous experiences to draw upon, leaders grapple with not only how to make sense of a situation but also how to frame the situation when they themselves may not have a firm grasp of what it means for the future.

Precisely this predicament - how to engage in persuasive public meaning making when your own backstage sense making is continuing and problematic-has been faced by the leaders studied in this volume. It formed the core of the interest with which this study began.

How do leaders resolve this predicament? It depends. Crisis communication scholars tell us that

leadership can have a positive or negative impact on the development of a crisis. Leadership can be a positive force by helping to frame the meaning of a crisis event, expressing appropriate concern and support, overseeing mitigation, coordinating support, and facilitating timely, open communication. In many cases, however, crisis leadership is characterised by strategies minimising harm, denying responsibility, and shifting the blame (Seeger et al. 2003:241).

The crisis exploitation model presented in Chapter 2 and used by the case study authors to interpret the verbal behaviour of the chief economic policymakers of nine polities offers some ideas about why crisis leadership can evolve in one way or another. Put in Clausewitzian terms, it claims that crises constitute the continuation of politics as usual by other means. When extraordinary events occur, continuing struggles for political ascendancy do not cease; they can intensify. The same goes for continuing debates about public policy, which can be jolted in one way or another by the challenges crises pose to the resilience of existing governance ideas and practices. 
When the unexpected happens, public leaders become the focus of intense attention. In a context of uncertainty and stress, they have to act on the public stage - to talk sensibly, to steer people's beliefs and emotions, to project authority. They have to do so, however, in the knowledge that the very occurrence of a crisis puts them under intense scrutiny. Their past and their present performances will be judged in a new light. The political price of a slip of the tongue, bad timing or clumsy dramaturgy can be considerable - for government leaders and their chief rivals alike. There are, however, also considerable gains to be achieved from capturing the public's ear and gaining its support for one's portrayal of the crisis and the ways in which it could best be managed.

It was in this high-stakes, mixed-motive context that the leaders studied here talked about the economic catastrophe that was unfolding before their and our eyes. Some might have felt overwhelmingly threatened by the crisis, whereas others might rather have sensed the opportunities it presented to them. Some were good at reading the writing on the wall and did not hold back in depicting the depth of the problems. Others were keen to keep the wolves at bay by projecting optimism. Some were keen to publicly justify their past policy stances; others focused on using the crisis to leverage policy change. In this chapter, we reflect on what these studies can teach us about the nature, use and limits of rhetoric in taming and exploiting crises.

\section{Hard realities versus soft talk}

And what a crisis it was. Once it went beyond its origins in the US mortgage market, the financial meltdown hit most of the Western world hard and fast. It presented governments and citizens with a set of stark, undeniable, immediate realities. Share markets tumbled, with hundreds of billions of dollars wiped off capital assets day after day. Real estate prices came tumbling down in places such as New York, London and Singapore. Once mighty corporate empires filed for bankruptcy. Others came hat-in-hand to the government to be bailed out or were taken over. The International Monetary Fund (IMF), the Organisation for Economic Cooperation and Development (OECD) and other global economy watchers weighed in with ever more pessimistic outlooks. The world saw bank runs, Iceland going broke, Wall Street suicides, mass sackings, repossessed homes, abandoned construction sites. In 2009, virtually all major economies were experiencing what economists awkwardly called 'negative growth'. And for those who cared to look for them were the shattering consequences of falling Western demand in the developing economies of the world.

During the months scrutinised most closely in this volume, these were the hard realities of the financial collapse and the economic downturn it triggered. With 'the facts' so incontrovertibly on display for all to see, and so many to acutely feel, there were definite limits to what leaders could aspire to when it came to 
shaping and bending public perceptions of the severity of the economic problems that had arisen. The upbeat, euphemistic 'business as usual' talk that some of the leaders studied here used to downplay the crisis during its initial stages was so patently disproved by the material realities of the downturn that-sooner rather than later - most of them staged a rhetorical retreat from crisis denial (type-1 rhetoric, in Table 2.1) to crisis acknowledgment (type-2 rhetoric).

Although ours has been a study of rhetoric as the main instrument of crisis leadership, the findings of the case studies teach us an important lesson: if material realities are hard, immediate and widespread enough, political and even expert talk becomes soft in comparison. In terms of framing the problem and putting it right at the top of the political agenda, the brute facts lead and public discourse has to follow, leaving less scope for 'spin' than politics in normal times does.

In this, the financial crisis stands in marked contrast with the other great crisis of the present era: climate change. The politics of climate change have long been dominated by framing contests about the very nature of the problem (Pettenger 2007). Does it exist? How bad is it now and how much worse will it become? What is causing it? The reasons for this difference are not hard to spot. Whereas the downturn hit the very financial centres of the Earth first in immediate and devastating fashion, the realities of climate change were much harder to spot and interpret. Much of the debate was based on models and projections, not directly observable facts. Some of the more conspicuous forms of ecosystem change (mostly degradation) that did occur in real time were found mostly in far-flung places such as the polar zones or tropical rainforests. Moreover, even when such effects were registered and caused wider public concern, it was not immediately obvious that 'climate change' was the prime cause. Softer facts, longer timelines, more selective and ephemeral impacts, tenuous causal links - climate change was bound to offer much more of a rhetorical battleground than the global financial crisis. It had to be 'sung into existence' (Patterson and Stripple 2007) rather than imposing itself abruptly and non-negotiably on the world, as the financial meltdown by and large did. The framing contest around the existence of climate change and its deleterious effects has long been the main game; the framing of the severity and causal nexus underpinning the financial meltdown quickly became a sideshow. It was a space that almost all of the policymakers studied here abandoned quickly, leaving it to small tribes of ideological warriors - masking as economists - to fight over what the rest of the world now felt was a trivial question. However flimsy their arguments are gradually becoming, after decades of research and debate, there are still numerous climate change deniers in the world today; but there never have been and never will be global financial crisis deniers. 
The fact that the existence of a severe crisis that had its roots in the US sub-prime mortgage sector and spilled over into its financial institutions at large quickly became a non-issue did not mean that there was no space for social construction and thus political contestation in the management of the financial crisis. On the contrary: as the case studies demonstrate, policymakers within and across countries often proposed markedly different interpretations when it came to questions of responsibilities and remedies.

Consider the question of responsibilities first. There was much scope for externalising versus internalising that issue and (de-)politicising the accountabilities of public office-holders and institutions accordingly. Even if the root causes were exogenous (in the United States, in the market sector), were our own financial systems resilient enough to absorb the market distress? Were our regulatory practices instrumental or detrimental to this resilience? Were the incumbent policymakers alert enough to spot the problems early on and did they take sensible measures to curb their impacts? Or did their early interventions in effect aggravate the crisis rather than contain it (for example, Taylor 2009)? These questions were never far from the minds of the speech-makers we studied and were certainly on the minds of those reporting their speeches and holding them accountable politically.

The same goes for the question of policy implications. In all the countries studied, policymakers faced the same predicament: what do we do now? Nationalise banks? Subsidise or take over 'strategic' corporations more widely? Slash taxes; which ones and by how much? Offer cash payments? Redesign financial regulation? Go at it alone in protecting domestic industries? Or develop economic stimulus and pursue reforms in regional and global arenas? Bewildering as the sheer magnitude and hitherto unthinkable nature of some of these policy predicaments might have seemed, astute policymakers would have been quick to see possible silver linings behind the clouds of the current crisis. Perhaps it was a good time to use the crisis as cover for one's pet policy innovations that would otherwise be politically impossible to achieve?

In the remainder of this chapter, we dig a little deeper into these two clusters of questions, corresponding to what we in Chapter 2 call the political game (about responsibility and accountability) and the policy game (about preserving and innovating modes of governing) of crisis exploitation. In these games, elite rhetoric inevitably plays a key role, no matter how 'hard' are the facts of the crisis at hand. In the latter part of the chapter, we tease out some recurrent patterns in the crisis rhetoric of the public office-holders studied here. We conclude by reflecting on the limitations and implications of this study. 


\section{Who done it? Rhetoric of responsibility and blame}

In his book Credit and Blame, Charles Tilly (2008:13) reminds us that responsibility does not necessarily equal cause. Your judgment, my judgment, and a medical specialist's judgment as to what actually caused a given hospital patient to die often turn out to be irrelevant for the assignment of blame. Cause-effect connections usually play only a secondary and contingent part in determination of responsibility. That determination typically emphasises judgments of intent and competence.

Likewise, Bovens and 't Hart (1996:137-8) observe:

The crucial-but often implicit - question in...debates [about the causes of disasters] is where, when and how misfortune stops and mismanagement begins...Some failures have such grave consequences or pose such a threat to our worldview or sense of justice that 'bad luck', however appropriate in empirical terms, will not be accepted as an explanation. Especially those who have been injured will continue to look for someone to blame.

Anticipating and managing blame have become second nature to contemporary politicians and public servants. In an era of high visibility, floating voters, declining trust in traditional elites and institutions and collective obsession with risk and danger, those who govern and their servants are answerable for an awful lot. They have learned that when the news is bad, and the policies they have to sell are about retrenchment, contraction, redistribution benefits or allocating risks, the 'politics of pain' set in, with 'blame avoidance' being the name of the game (Pierson 1994; Hood 2002; Pal and Weaver 2003). So, when confronted with the biggest financial and economic breakdown in well more than half a century, the holders of executive office studied here knew there would be blame games to play. No matter that there was little dispute about the causal narrative of the crisis: this problem was 'made in America'. This put former US President George W. Bush et al. on the spot, but implied that all the others were essentially off the hook. Nevertheless, most of them must have known that the story would not end there. Although the root causes of the credit crunch might have been beyond their control, nasty questions might still present themselves. Why did you not see it coming? Was our financial system really as resilient as it could have been? Did you do enough to mitigate the impact of the crisis once it was under way? Why have you not been leaning much harder on corporate excess? In making meaning about the developing financial crisis, therefore, our policymakers were not just managing the issues themselves; they were managing the potential political fallout from the issues. They also knew that other public voices-oppositions, sceptical journalists, expert besserwissers - would weigh in on the framing of responsibility. 
As Table 2.1 suggests, they had roughly two options: deny all responsibility or accept that they could have done more and better in at least mitigation. Likewise, journalists, non-governing parties and other actors in the debate had the options of absolving government actors from (co-)culpability or pinpointing blame on them. Depending on the configuration of their choices, different types of blame games could ensue. And although there were some notable differences, the similarities stood out most. Careful study of the speeches across the nine jurisdictions reveals the following general pattern.

- Issues of responsibility and blame do not enter the official discourse until the crisis is well under way, as the first impulse of most policymakers is to downplay the severity of the problems. They thus sidestep the very need for blame.

- Once past the denial stage, speech-makers make a concerted attempt to exogenise the causes of the crisis across territorial ('it's the Americans' or, in the case of Singapore, the West) and institutional ('it's the market') borders. The fallback position is thus to attempt to deflect blame.

- At the same time, virtually all of the politicians - unlike the national bank governors - attempt to moralise the issue, by accusing key corporate actors of 'greed', 'recklessness', 'unscrupulousness' and the like. They do some 'pinpointing' of their own. Like all blamers, they draw moral lines between 'them' and 'us' (Douglas 1992; Tilly 2008), so as to erase any doubt among their audiences about who is at fault (and who, by implication, should get off scot-free).

- Virtually all speakers engage in attempts to 'jump over' blame, by moving straight from assessments of severity and causes to talk about the need for regulatory reform in the financial sector, domestically but most emphatically at the international level (see further below). This is a rhetorical feat: the system is broken and should be fixed, but let's not talk about who should bear responsibility for it being broken in the first place.

- And finally, a limited number of speakers engage in some form of admission - not of 'guilt', but of the presumably lesser evils of naivety (about the extent to which perverse incentives in the financial sector have bred deep cultures of corporate irresponsibility) and lack of vigour in tightening regulation. All stop well short of public contrition, though a few acknowledge and empathise with the extent of suffering borne by the ordinary citizens who have been the losers in the crisis.

In all, this pattern corresponds closely with the findings of other studies of blame management - namely, a pattern of 'staged retreat': the potential blamee tries to keep the discussion about blame as far away as possible from themselves, but as the pressure on them increases (because new facts become known, more people have become angry or credible other voices are starting to question their 
involvement, competence or intent), they retreat to less ideal but still potentially workable forms of blame avoidance (Bovens et al. 1999; Brändström and Kuipers 2003; Hood et al. 2007). It is important to note that none of the policymakers engaged in proactive acceptance of responsibility, forfeiting the option of ending up in the relatively benign 'blame minimisation' game type, in which early and forthright public acknowledgment of responsibility gets the blamee 'off the hook' in the media and parliamentary arenas (see Table 2.1; for empirical illustration, see Brändström et al. 2008).

This general pattern was punctuated by several differences of timing and emphasis. For example, Singaporean and European Commission leaders did not budge in their responsibility rhetoric; in contrast, UK policymakers, particularly Chancellor, Alistair Darling, eventually did engage in some acknowledgment of responsibility. What factors might have caused such differences? They are mainly contextual, underlining that there is truth in the cliche that where one stands depends on where one sits. On the basis of the case studies - and other than obvious factors such as personal beliefs and styles or being in versus outside government - we would nominate the following factors.

- Salience of accountability pressures: lacking real media or legislative scrutiny in these matters, Singaporean and European Commission policymakers could afford to gloss over questions of responsibility.

- Type of office held: much of the political heat of accounting for the crisis fell on the politicians and there were at times marked differences in the responsibility rhetoric of heads of government and finance ministers on the one hand, and bank governors on the other (only the retired US Federal Reserve chairman Alan Greenspan, in a Congressional hearing in October 2008, came out with a highly publicised acknowledgment of responsibility). The bank governors, as bureaucrats, were able to concentrate more on diagnosing and managing the operational crisis. They therefore generally steered clear of statements that could lead others to question their past prudence, lest these might spill over into doubts about their present competence in crisis response.

- Length of incumbency: obviously, policymakers such as UK Prime Minister, Gordon Brown, former New Zealand Prime Minister, Helen Clarke, and Irish Taoiseach, Brian Cowen, who had held an executive leadership position for several years before the occurrence of the crisis, were more at risk in discussions about responsibility than their counterparts such as Australian Prime Minister, Kevin Rudd, incoming New Zealand Prime Minister, John Key, and US President, Barack Obama (and their treasurers), who took office just before or in the middle of the crisis. The latter were far better able to credibly shift blame to others - notably, their predecessors. Some in effect presented themselves primarily as blamers, not blamees, with US Treasury 
Secretary, Timothy Geithner, and Rudd the most conspicuous examples. Conversely, some opposition politicians during the crisis were muted in their criticism of government passivity in the face of a growing bubble that was waiting to burst only because they themselves had been in government in the years leading up to the meltdown. It shows that Table 2.1 ignores the crucial influence of temporal factors (and thus possible role changes and factors mediating media predispositions towards the responsibility rhetoric of various elite actors) in its prediction of the nature of crisis-induced blame games. Determining who blames and who accounts is not a matter of taking a snapshot view of a crisis; it instead requires understanding crises in terms of the unfolding of a much longer political scenario.

In the end, there was surprisingly little hardball politics of blaming going on during the period under study. Yes, the crisis became a prominent election issue in New Zealand, the United States and, to a lesser extent, Canada. In Canada, however, the incumbents survived, whereas in New Zealand and the United States, one had the distinct impression that the loss of the incumbents (or their parties) was over-determined to begin with by a host of other factors.

Perhaps the immediate challenges of absorbing and taming the crisis were too overwhelming (and controversial). This suggests that blame still needs to be apportioned later - for example, in the context of the inevitable inquiries that are being announced in various countries at the time of writing. Perhaps blame was effectively privatised in this case, with impoverished account holders and investors chasing financial executives in the courts. Perhaps, however, there simply was not enough semantic space and political appetite left for pinpointing blame domestically for a fiasco that has widely become labelled as the global financial crisis. Anthropologists might be on the mark in observing that those who have been injured will always look for someone to blame; but if the victims are in their millions scattered across the planet, the more likely it is that the search will be fruitless. It is the ultimate 'many hands' problem: the more 'global' the crisis, the larger the number of hands that have helped bring it about and the easier it is for incumbent elites to successfully engage in blame-avoidance rhetoric, with blame ultimately evaporating rather than crystallising.

\section{What now? Rhetoric of policy and reform}

The global financial crisis spawned a wide array of ad hoc measures and policy interventions. More broadly, the crisis produced a great deal of reform rhetoric from leaders and from opposing parties and interest groups. The presence of such contests forced leaders into the position of status quo player or change advocate, and choose between preserving or innovating modes of governing.

Previous research into economic crises suggests that governments react strongly to the prospect of mass unemployment. Moreover, the negative public sentiment 
that comes with the threat of mass unemployment provides governments with a greater mandate for action (Keeler 1993). Furthermore, economic crises produce 'opportunity windows for reform' that governments can harness (Baumgartner and Jones 1993; Kingdon 1995; Wilson 2000). Therefore, while economic crises might limit governments' budgets, they also allow policymakers greater scope to implement reforms that would otherwise be met with fervent opposition. The reason is simple: ever since former US President Franklin D. Roosevelt stepped in to stem the tide of the Depression through proto-Keynesian government activism, the public expected governments to 'do something' in times of recession and rising unemployment. Governments can capitalise on that momentum by packaging tailor-made reactions to the current economic circumstances along with additional policies it had wished to implement all along but which can now be reframed as forming an integral part of the recession-busting strategy (Rodrik 1996). This was evident in many of the polities studied in this volume. In Australia, the 'education revolution' and climate change technology became part of the reform rhetoric, as did European unity and integration in the EU leaders' reform rhetoric.

Kuipers' (2006) work on policymaking and 'competing crisis narratives' claims that crises open up space for actors to construct their own crisis narrative. A leader or opposition group can utilise crisis narratives to describe their own version of events and propose reform to adapt the system to meet the exogenous changes and the new challenges. Nevertheless, to be effective, the narrative must be in sync with, or speak to, the experience of the broader public (Hay 1999, 2002). Kuipers (2006:181-2) notes four indicators that a crisis narrative is being constructed: the use of the word 'crisis' to describe an undesirable situation; claims that the situation is urgent and requires drastic action; when the broader public is asked to comply with reforms or the leader appeals to solidarity during the crisis, as in wartime; and when the complex crisis situation is simplified or the leader makes use of metaphors and historical analogies to explain the situation. When these narratives catch on and are accepted by the public, they pave the way for reform in the system. Each of the polities studied in this volume displayed some if not all of these elements of crisis narratives in relation to policy and reform.

The leaders studied here needed to determine what they believed to be the right course of action. At the same time, however, they were held accountable for their decisions and had to articulate their strategic actions and their policy moves (or even others' policy moves) to the public. Their policy moves were at times reactive and improvised, as they needed to rhetorically prime their audiences in the rapidly evolving situation.

The policy game laid out in Chapter 2 of this volume suggests that leaders take one of four rhetorical positions. As a 'change advocate', they might press for a 
policy paradigm shift or for incremental reform, or as a status quo player, they might attempt to resist or contain policy change. Opposition parties, unions and interest groups, sections of the media and/or demographics of the public might take up the other side of the contest.

The case studies demonstrate that the model's assumption needs to be refined. We encountered a couple of interesting situations where both sides of the contest were pro-reform. Disagreement and contest instead centred on the specific policies that should be implemented - or more often, the scope and pace of the proposed reforms (incremental versus paradigm shift). For example, in the United Kingdom and Australia, the head of government and the opposition leader both claimed to favour some kind of reform. At the same time, Prime Ministers Brown and Rudd both attempted to portray their opposition leaders, David Cameron and Malcolm Turnbull, respectively, as advocates of the old 'failed' system. In Australia, this caused problems for Turnbull, particularly as the media remained largely supportive of the government. In contrast, for Cameron, Brown's strategy did not make much of a dent as the media and public were quick to note that Brown had had 11 years in which to offset the alleged flaws of the 'neo-liberal' economic philosophy of the previous Conservative governments and had apparently missed the opportunity to do so. Blaming predecessors is simply not credible in these circumstances.

At times, the media was more focused on the leader's behaviour and style than on the government's policy. For example, in Canada, Prime Minister Stephen Harper's alleged lack of sensitivity to the suffering of ordinary Canadians became a key storyline, much more so than the critical vetting of the substance of his statements - at least for a while.

Our case studies suggest some recurrent patterns in the policy component of leaders' crisis rhetoric. One was the prevalence of bricolage: combining tailor-made responses with essentially policy initiatives that were thrown in because they fit the leader's election promises or prior convictions or were skilfully brought to the leader's attention by advisers, bureaucrats and interest groups. As predicted by models of agenda setting and policymaking that stress the role of contingency and opportunism (for example, Cohen et al. 1972; Baumgartner and Jones 1993; Kingdon 1995), the economic crisis spurned actors to advance ideas and proposals that would otherwise not be accorded the same attention or levels of funding. For example, in Australia and the European Union, the crises speeded up initiatives to (re)invest in green technology. In Ireland, it provided momentum to Prime Minister Cowen and Finance Minister Brian Lenihan's 'Framework for Economic Renewal'.

Some leaders managed to successfully incorporate non-economic policy into crisis rhetoric. After the Australian Government's announcement of the major stimulus package that would send the economy into deficit, opinion polls 
indicated that the public was strongly in favour of spending on renewable energy, tax cuts and other projects for the betterment of society, which made up the package, but comparatively, they were somewhat less supportive of the package as a whole or of the notion of large-scale deficit spending. As such, it was rhetorically prudent for Australian leaders to highlight the benefits of the package to particular, high-priority policy sectors. This highlights the importance of matching the crisis narrative to the felt experiences of those on the ground (Kuipers 2006) - something at which some leaders, such as Obama, excelled and others, such as Brown and Harper, failed.

Second, the policy contests that ensued in the course of the crisis were to a considerable extent fuelled by underlying ideological disagreements. In some cases, leaders spent considerable rhetorical effort attacking 'neo-liberalism' and its free-market policies, with the Australian and Singaporean Prime Ministers leading the way. Conversely, the New Zealand case demonstrated how the same set of events was utilised by incoming Finance Minister, Bill English, to push for less rather than more government regulation of financial markets. This position was taken up by some Republicans and Hayekian economists in the United States, but was clearly repudiated by Obama and Geithner. Debates about the merits of stimulus packages in most of the countries studied appeared to hinge not on the size of projected deficits, but on the underlying beliefs about the relative merits of 'big' versus 'lean' government.

Third, the global nature of this economic downturn created an extra dimension for political leaders - one that they could use to their advantage. The majority of political leaders highlighted the international dimension of the crisis, not simply to blame exogenous forces, but when discussing reform or policy implementation. During a crisis, there is often a need for leaders to appear action orientated, but domestic opposition might tie their hands in taking bold initiatives. Calling for, organising and visibly working with peers, however, in ad hoc meetings of international forums such as meetings of the G7, G8 and G20, EU conferences and regional summits provides national leaders with excellent opportunities for 'self-dramatisation' (Edelman 1977). It also helps supranational leaders (such as European Commission President, José Manuel Barroso) make the case for the pivotal role their institutions can play in forging common approaches to what are clearly trans-boundary crises.

Advocating international reforms also allowed leaders to perform the balancing act of appearing as proactive change agents while in the same breath talking up the strength of their domestic economies and defending their record in regulating their national financial sectors. It also shifted part of the policy game to international arenas where domestic opposition forces had no seat at the table. Internationalisation of crisis rhetoric was evident to a different degree and for a different purpose in each of the cases. For French President, Nicolas Sarkozy, 
the EU Presidency was a chance for France (and Sarkozy) to be heard; for the United Kingdom, hosting the G20 was a chance to appear in charge and at the centre of the solution. For the open economies of Singapore, New Zealand and Ireland, however, the global dimension of the crisis was mainly a source of despair rather than a feasible source of relief.

Fourth, the leaders' past records greatly shaped and constrained their ability to credibly advocate particular policy stances. Some leaders had been in charge of their country's financial regulation and economic policy for a long time when the crisis materialised. For example, UK Prime Minister Brown and Irish Taoiseach Cowen had both been treasurers in long-serving governments before taking over as party leader and head of government. Canada's Prime Minister Harper had built much of his authority on his reputation as an astute economist. The public deference this generated appeared to buy him time when the crisis first materialised, but then appeared to backfire as his optimistic predictions were defied by growing unemployment cues. In Ireland, it was impossible for Cowen to escape criticism for his old policies when attempting to introduce new ones.

Fifth, the least prominent yet also the least criticised speech-makers in our set were the bank governors. Although in normal times bank governors are key figures in interpreting economic realities to investors and entrepreneurs, during the hottest months of the global downturn, their speeches were often eclipsed by the attention paid to the words and actions of the heads of government. When the going gets tough, it is clearly the politicians rather than the technocrats who are monitored most closely by the media and the public.

Though perhaps their relative visibility was low, their credibility might have been higher than that of the government leaders, particularly the long-serving ones for whom the crisis was first of all a source of potential electoral embarrassment. In contrast, the bank governors' statutory independence and reputation as non-aligned technocrats protected their credibility, with media coverage of their speeches on balance far less critical than that of politicians' speeches. In the US case, the picture was more complicated. Former US Federal Reserve Bank Governor Alan Greenspan's very public admission of having made critical errors of judgment that had allowed the monster of the mortgage bubble to grow unchecked could have dented public confidence in his successor, Ben Bernanke. Bernanke moreover struggled with having to manage the biggest crisis of the financial system he is supposed to help preserve while at the same time having to adjust to the political transition from the Bush to the Obama Administrations.

Some bank governors were vocal and visible. In Australia, Reserve Bank Governor, Glenn Stevens, was the first of the Australian leaders to broach the issue of deficit spending, and only after the media picked up on this did the Prime Minister and Treasurer actively discuss in public what would later become 
a reality. Most governors were not publicly known figures before the crisis but came to be seen as significant players. In the United Kingdom, Bank of England Governor, Mervyn King, became part of a media-perpetuated controversy speculating on a rift between him and the government. In Ireland, Governor of the Central Bank and Financial Services Authority, John Hurley, was respected for staying on past his retirement date. In many cases, including Ireland and Australia, the central bank governor was seen to 'inject reality' into the rhetoric. In contrast with the coverage of the politicians' speeches, the overwhelming tendency was for journalists not to focus on the personal characteristics and political beliefs and interests of the governors, and instead concentrate on the substantive merits of their policy arguments.

Finally, the speeches were notable for their strategic uses of the past. Popular in leader rhetoric during the global financial crisis was the use of historical analogies to simplify explanations and manage public sentiments. Australia's Treasurer, Wayne Swan, used the analogy of Hurricane Katrina to convince his audience that through crisis came a better understanding of underlying weaknesses in a system. Various leaders likened the crisis to an 'economic tsunami', tapping into recent global memory to underline the severity of the crisis. Predictably, virtually all leaders invoked the Great Depression of the 1930s when attempting to maximise the severity of the recent downturn, but they also used historical analogies to 'sell' policy. Brown and Darling tried on several occasions to sell their policy proposals using the analogy of the Bretton Woods agreement (as did leaders in France and Australia) and even the Marshall Plan. President Obama drew analogies from throughout US history of economic policy that spurred great change and modernisation, and this rhetoric seemed to resonate. The Singaporean Prime Minister tapped into the well of the Asian financial crisis of the 1990s to highlight his government's preparedness and the claimed superiority of the country's regulatory regime (which had already incorporated the lessons the Western countries would now be forced to learn all over again).

The point about using analogies in meaning making is not that they are correct; it is that they resonate - as opposed to their use in the leaders' own sense making, when incorrect analogies can fatally wound the diagnostic capacity of leaders (Brändström et al. 2004). When analogies are widely challenged, they backfire. When they appeal to universal symbols and are carefully crafted and timed, however, their metaphorical power in weaving a crisis narrative (Kuipers 2006) can do more to shape public perceptions of a crisis than any set of facts and charts is able to.

\section{So what? Final reflections}

We need to place this study in proper perspective. Our findings are to be regarded as setting the stage rather than speaking the final word on the power 
and limitations of elite rhetoric in the global financial crisis. For all its faults, however, this study does raise a few larger questions about leadership, rhetoric and crisis that we will flag in this last section of the book, as a potential bridge from this study to its as yet unwritten successors.

\section{Nostra culpa: flaws and limitations}

There is no denying that our effort has been a limited one in several key respects. In particular, we should note that we studied only three public office-holders per country - those who were most intimately involved in macroeconomic management - and thus possibly failed to register publicly voiced differences and disagreements within the government. We selected only a limited number of speeches per office-holder, not replicating Wood's (2007) towering effort of studying each and every word they uttered on the crisis, so there is a risk of sampling bias. The speeches we selected here might not have captured the full breadth or all the twists and turns over time in the rhetoric of the leaders involved. We focused exclusively on speech-makers on the government side of politics, thus excluding the voices of non-governing parties and interest groups. We adopted a fairly crude set of measures of assessing media responses, focusing on newspapers, and concentrating on broadsheets at that, for the most part ignoring the electronic media and the tabloids whose reach alone might have made them at least as salient a venue for registering the 'vox populi' when it came to the public reception of crisis rhetoric. We looked at public opinion data where available and to provide a contextual backdrop, but we know that caution should be exercised when attributing (changes in) leaders' approval ratings to a particular speech or action by that leader.

We hope - and expect - that in years to come, others will revisit the ground covered in this study more comprehensively and methodically than we have been able to in the short time frame we imposed on ourselves. It remains to be seen whether such exercises will refute, complement or merely reinforce the conclusions of the case studies and the general observations offered here. For the moment, the obvious limitations of this study will not stop us from leaving the reader with a few final questions and reflections that have emerged from it.

\section{Does rhetoric matter?}

This leads into a larger question: does leader rhetoric matter at all? Allan McConnell's chapter reminds us that leaders always strive for political and policy success, and rhetoric is one of the tools they employ to achieve it. The question is how powerful a tool it really is. Or, perhaps more sensibly, to wonder whether crises lend themselves well to management by speech. It is hard to deny that there are times when rhetoric - words plus the dramaturgy involved in their delivery-matters a great deal in politics. No one who closely followed the dramatic 2008 US election campaign - overshadowed by the cascading financial 
crisis shattering its corporate giants - which delivered the United States its first African-American President, Barack Obama, would have failed to register the galvanising effect of his persona and presentation on a crisis-ridden nation desperately looking for new leadership. How powerful, however, was the rhetoric of the leaders studied here in naming, framing and taming the financial crisis? Can leaders speak 'words that succeed' even though the economic indicators of the day suggest that their policies are failing (Edelman 1977)?

This question is of interest to those scholars in political science and international relations who argue on either side of the debate between 'realism' and 'constructivism'. This debate comes in many guises and the proponents of the two positions use different labels to describe themselves. The main bone of contention, however, is whether political contests and outcomes are driven first and foremost by the material realities that they purport to shape or by 'ideas' (cognitions, beliefs, norms, tacit knowledge, models) that people have in their heads and that exist quite independently of those material realities (Bevir and Rhodes 2005, 2006a, 2006b, 2006c, 2008; Marsh and Furlong 2002; Furlong and Marsh 2007; Marsh 2008).

Our study would be of interest to each side in this debate. As we intimated in the opening section of this final chapter, the brute facts of economic breakdown that were unfolding on a daily basis during most of 2008 and the early months of 2009 greatly constrained the ideational space when it came to answering the question 'Is something bad the matter?' - as something so obviously was. And consequently, the heads of government, finance ministers and bank governors who initially attempted to do what they normally did when faced with a sluggish economy - talking it up-were forced to stage fairly rapid and significant rhetorical retreats. The leaders who had confidently asserted that their country was better prepared than anywhere else to withstand the temporary turbulence caused by problems in US financial markets (and words to that effect) did not offer a pretty sight. All had to back down from their repeated and emphatic assertions about their own system's resilience and admit that this crisis was not going to pass them by. They received a hard lesson in the full extent of economic globalisation: along with sharing the benefits of open markets and interdependencies comes a share of negative spill-overs - and little can be done to avoid them. Only in Singapore and Canada did leaders hold out a bit longer - in Canada because the Prime Minister genuinely seemed to believe he knew better and was not convincingly corrected by experts or credible opposition counterparts, and in Singapore because of the lack of opposition. By late 2008, even their staunch optimism had to give way to preparing the public for pain.

There is also much in this study for constructivists to consider. The differences within and between countries on how to combat the crisis were sometimes stark. They were the product of pre-existing beliefs, more so than of material realities 
or interests. Regardless of how badly their particular country was affected by the downturn, fiscal conservatives and free marketeers blamed misguided regulation and ill-designed bailouts for the escalation of the problems. They consequently advocated a less-constrained market rather than government intervention as the ultimate solution for the crisis. They deplored the level of indebtedness their ideological opposites were getting taxpayers into as a result of the stimulus packages they were proposing. In contrast, 'neo-Keynesians' and other advocates of activist government saw this crisis as the perfect bankruptcy of their ideological opponents' long dominance in political-economic thought and policy. They therefore dubbed the crisis the greatest market failure in modern history and their rhetoric readily adopted the language of government as pivotal regulator and wealth defender.

\section{Whatever happened to rallying around the flag?}

One of the conventional wisdoms of political science is that in times of crisis, people 'rally around the flag'. That is, they lend their support to whoever happens to be in charge of the government. The first Gulf War was a classic case in point. American and global public opinion wholeheartedly embraced the White House's definition of the situation: evil dictator invades harmless, oil-rich neighbour, and it is the duty of the world community to not let him get away with it. The 9/11 attacks in the United States generated pretty much the same response - as the 1982 Argentinean invasion of the Falklands Islands had done within the United Kingdom (Lai and Reiter 2005). The phenomenon has been associated in particular with international security crises, although detailed studies have demonstrated that the strength of the effect is highly variable depending on, among other things, whether the conflict involves real war and the way in which it is reported in key media outlets (Oneal and Bryan 1995). The phenomenon has parallels in the world of natural disasters, where researchers observe the emergence of 'altruistic communities' and 'prosocial behaviour' - people setting aside their daily routines and their political differences to help those affected by the destruction (Dynes 1970:84; Tierney et al. 2001).

Leader rhetoric can help bring about the effect and in return leaders can be important beneficiaries of its occurrence (Schubert et al. 2002). That is why leaders like to 'securitise' problems: framing them as threats to core national values and interests (Buzan et al. 1998; Eriksson 2002). Doing so successfully lifts these issues above the fray of day-to-day politics and elevates the leaders in question to key managers of the national interest (rather than spineless, poll-following opportunists).

This being the case, a puzzle presents itself: why did we see so little of this in evidence in the case of the global financial crisis? A striking feature of media and public opinion responses to the leader speeches is how guarded or even 
overtly critical the majority of them are. This surprised us. Surely a crisis of this magnitude lent itself to securitisation, in that a credible case could have been made that the very foundations of national prosperity were at stake? It is perhaps not so surprising that a fading leader such as Bush, who arguably had already gone 'one war too far' in Iraq (McAllister 2006) and whose reputation for crisis management was fatally tarnished in the wake of the Hurricane Katrina fiasco (Preston 2008; Boin et al. forthcoming), could not pull this off — but neither could his much-vaunted successor nor many of the other heads of government studied here. In his October address to the nation, Rudd certainly tried to rally Australians in 'the economic equivalent of a national security crisis', but this did not remain a dominant theme. Perhaps it is because economic downturns come without enemies that can be stigmatised and inflated to mobilise support for the government ('corporate greed' was tried by almost all leaders, but never really settled in the public's mind as the prime culprit).

In fact, although they might feel counterintuitive, our impressions are in fact in line with the results of public opinion research that suggests that head-of-government popularity takes a dive when the economy does likewise. The leadership lesson that can be drawn from this appears to be as follows: you might be able to frame your way into popularity during war and disaster, but you cannot frame your way out of unpopularity in a recession (nor should you expect to get the credit for economic booms in the same way that you might for winning wars; cf. Kinder 1981). As Bengt Sundelius reminds us in his chapter, inconvenient or ill-managed crises can drive leaders out of a job and governments out of office.

\section{A crisis in progress}

The 'quick response' approach to the social science research of this volume deconstructs a process that is still evolving. In that sense our study is shooting at a moving target. At the time of writing, the majority of polities studied in this volume had not undergone a major post-crisis election. It will be a process worth observing as the rhetoric of blame and reform is likely to be brought to the fore. Political careers and institutional futures will inevitably rely on the result of the continuing political and policy framing contests triggered by the economic downturn. It is too early to tell whether the paradigm shifts or overhauls of current regulatory institutions and practices advocated by some will materialise. A considered answer to one of this volume's central questions - concerning the success of the meaning-making efforts of these leaders - can be provided only by a subsequent study, conducted when the waves produced by the current crisis have fully settled.

One thing is clear, however: the economic downturn has opened the floodgates of economic orthodoxy and regulatory practices underpinning the political management of the market economy within states and across the international 
system as a whole. Time will tell who will emerge as the winners and losers among the elites and institutions most closely involved in the framing contests that lie at the heart of the reform struggles that are picking up momentum as this book comes to a close.

\section{References}

Baumgartner, F. R. and Jones, B. D. 1993, Agendas and Instability in American Politics, University of Chicago Press, Chicago.

Bevir, M. and Rhodes, R. 2005, 'Interpretation and its others', Australian Journal of Political Science, vol. 40, no. 2, pp. 169-87.

Bevir, M. and Rhodes, R. 2006a, 'Defending interpretation', European Political Science, vol. 5, no. 1, pp. 69-83.

Bevir, M. and Rhodes, R. 2006b, 'Disaggregating structures as an agenda for critical realism: a reply to McAnulla', British Politics, vol. 1, no. 3, pp. 397-403.

Bevir, M. and Rhodes, R. 2006c, 'Interpretive approaches to British government and politics', British Politics, vol. 1, no. 1, pp. 1-29.

Bevir, M. and Rhodes, R. 2008, 'The differentiated polity as narrative', British Journal of Politics and International Relations, vol. 10, no. 4, pp. 729-34.

Bligh, M. C. and Hess, G. D. 2007, 'The power of leading subtly: Alan Greenspan, rhetorical leadership, and monetary policy', The Leadership Quarterly, vol. 18, no. 1, pp. 87-104.

Boin, A., McConnell, A., 't Hart, P. and Preston, T. (forthcoming), 'Leadership style, crisis response and blame management: the case of Hurricane Katrina', Public Administration.

Bovens, M. and 't Hart, P. 1996, Understanding Policy Fiascoes, Transaction, New Brunswick.

Bovens, M., 't Hart, P., Dekker, S. and Verheuvel, G. 1999, 'The politics of blame avoidance: defensive tactics in a Dutch crime-fighting fiasco', in H. K. Anheier (ed.), When Things Go Wrong: Failures and breakdowns in organizational settings, Sage, London, pp. 123-47.

Brändström, A. and Kuipers, S. 2003, 'From "normal incidents" to political crises: understanding the selective politicization of policy failures', Government and Opposition, vol. 38, no. 3, pp. 279-305.

Brändström, A., Bynander, F. and 't Hart, P. 2004, 'Governing by looking back: historical analogies and contemporary crisis management', Public Administration, vol. 82, no. 1, pp. 191-210. 
Brändström, A., Kuipers, S. and Daléus, P. 2008, 'The politics of blame management in Scandinavia after the tsunami disaster', in A. Boin, P. 't Hart and A. McConnell (eds), Governing After Crisis: The politics of investigation, accountability and learning, Cambridge University Press, Cambridge, pp. 114-47.

Buzan, B., Waever, O. and de Wilde, J. 1998, Security: A new framework for analysis, Lynne Rienner, London.

Cohen, M. D., March, J. G. and Olsen, J. P. 1972, 'A garbage can model of organizational choice', Administrative Science Quarterly, vol. 17, no. 1, pp. 1-25.

Douglas, M. 1992, Risk and Blame, Routledge, London.

Dynes, R. R. 1970, Organized Behavior in Disaster, Heath, Lexington.

Edelman, M. 1977, Political Language: Words that succeed and policies that fail, Academic Press, New York.

Eriksson, J. (ed.) 2002, Threat Politics, Ashgate, Aldershot.

Furlong, P. and Marsh, D. 2007, 'On ontological and epistemological gatekeeping: a response to Bates and Jenkins', Politics, vol. 27, no. 3, pp. 204-7.

Hay, C. 1999, 'Crisis and the structural transformation of the state: interrogating the process of change', British Journal of Politics and International Relations, vol. 1, no. 3, pp. 317-44.

Hay, C. 2002, Political Analysis: A critical introduction, Palgrave Macmillan, Hampshire.

Hood, C. C. 2002, 'The risk game and the blame game', Government and Opposition, vol. 37, no. 1, pp. 15-37.

Hood, C. C., Jennings, W., Hogwood, B. with Beeston, C. 2007, Fighting fires in testing times: exploring a staged response hypothesis for blame management in two exam fiasco cases, CARR, London, viewed 20 June 2009, $<$ www.lse.ac.uk/collections/CARR/pdf/DPs/Disspaper42.pdf>

Keeler, J. 1993, 'Opening the window for reform: mandates, crises, and extraordinary policy-making', Comparative Political Studies, vol. 25, no. 1, pp. 433-86.

Kinder, D. R. 1981, 'Presidents, prosperity and public opinion', Public Opinion Quarterly, vol. 45, no. 1, pp. 1-21.

Kingdon, J. 1995, Agendas, Alternatives, and Public Policies, $2^{\text {nd }}$ edn, Longman, New York. 
Kuipers, S. 2006, The Crisis Imperative: Crisis rhetoric and welfare state reform in Belgium and the Netherlands in the early 1990s, Amsterdam University Press, Amsterdam.

Lai, B. and Reiter, D. 2005, 'Rally around the flag, Jack: public opinion and the use of force in the United Kingdom, 1948-2001', International Studies Quarterly, vol. 49, no. 5, pp. 255-72.

McAllister, I. 2006, 'A war too far? Bush, Iraq and the 2004 US presidential election', Presidential Studies Quarterly, vol. 36, no. 2, pp. 260-80.

Marsh, D. 2008, 'What is at stake? A response to Bevir and Rhodes', British Journal of Politics and International Relations, vol. 10, no. 4, pp. 735-9.

Marsh, D. and Furlong, P. 2002, 'A skin, not a sweater: ontology and epistemology in political science', in D. Marsh and G. Stoker (eds), Theories and Methods in Political Science, Palgrave, Basingstoke, pp. 17-44.

Oneal, J. and Bryan, A. L. 1995, 'The rally round the flag effect in US foreign policy crises, 1950-1985', Political Behavior, vol. 17, no. 4, pp. 379-401.

Pal, L. A. and Weaver, K. R. (eds) 2003, The Government Taketh Away: The politics of pain in the United States and Canada, Georgetown University Press, Washington, DC.

Patterson, M. and Stripple, J. 2007, 'Singing climate change into existence: on the territorialization of climate policymaking', in M. E. Pettenger (ed.), The Social Construction of Climate Change: Power, knowledge, norms, discourses, Ashgate, Aldershot.

Pettenger, M. E. (ed.) 2007, The Social Construction of Climate Change: Power, knowledge, norms, discourses, Ashgate, Aldershot.

Pierson, P. 1994, Dismantling the Welfare State? Reagan, Thatcher and the politics of retrenchment, Cambridge University Press, Cambridge.

Preston, T. 2008, 'Weathering the politics of responsibility and blame: the Bush administration and its response to Hurricane Katrina', in A. Boin, A. McConnell and P. 't Hart (eds), Governing After Crisis: The politics of investigation, accountability and learning, Cambridge University Press, Cambridge, pp. 33-61.

Rodrik, D. 1996, 'Understanding economic policy reform', Journal of Economic Literature, American Economic Association, vol. 34, no. 1, pp. 9-41.

Rudd, K. 2008, Prime Minister's address to the nation, Parliament House, Canberra, 14 October, viewed 10 June 2009, <http://www.pm.gov.au/media/Speech/2008/speech_0553.cfm> 
Schubert, J. N., Stewart, P. A. and Curran, M. A. 2002, 'A defining presidential moment: 9/11 and the rally effect', Political Psychology, vol. 23, no. 3, pp. 559-81.

Seeger, M., Sellnow, T. L. and Ulmer, R. R. 2003, Communication and Organizational Crisis, Praeger, Westport.

Taylor, J. B. 2009, Getting off Track: How government actions and interventions caused, prolonged, and worsened the financial crisis, Hoover Institution, Stanford.

Tierney, K. J., Lindell, M. K. and Perry, R. S. (eds) 2001, Facing the Unexpected: Disaster preparedness and response in the United States, Joseph Henry Press, Washington, DC.

Tilly, C. 2008, Credit and Blame, Princeton University Press, Princeton.

Wilson, C. 2000, 'Policy regimes and policy change', Journal of Public Policy, vol. 20, no. 3, pp. 247-74.

Wood, B. D. 2007, The Politics of Economic Leadership: The causes and consequences of presidential rhetoric, Princeton University Press, Princeton, NJ. 